\title{
Commercially Centred Public Linguistic Space of the Russian City through English Signage
}

\author{
Elena B. Grishaeva* \\ Siberian Federal University \\ 79 Svobodny, Krasnoyarsk, 660041, Russia
}

Received 14.09.2016, received in revised form 15.10.2016, accepted 10.01.2017

The paper contributes into urban sociolinguistics, problematizing a modern city's signage as a field of sociolinguistic discourse. The aim of the study is to envisage commercially centered public linguistic space trough organized and implemented language management process, and to reflect language users' preferences and visual perceptions of linguistic tokens. Assessment of the city linguistic image has evidenced a sample of linguistic landscape discursive power and its symbolic role. From the qualitative research perspective, the paper examines resident's self-reported emotions and perceptions of the linguistic landscape, a micro context of cultural, social and linguistic mixing. The research implies results from contributive efforts of multidisciplinary approach to analysis of urban settings: sociology of language, language policy and planning, applied linguistics, cognitive linguistics and cross-cultural studies.

Keywords: Sociolinguistic discourse, public linguistic space, linguistic landscape, commercial shop signs.

DOI: 10.17516/1997-1370-0042.

Research area: philology; culture studies.

\section{Introduction}

Since 1990s, researchers have been developing a new domain of research close to the sociolinguistics of discourse, which is referred to as "urban sociolinguistics". They consider the city as a complex, heterogeneous and social entity that demands to be problematized as such. Urban sociolinguists study the city as a space where languages are displayed and written for a potential reader. This factor entails that urban signs are to be considered as discourses marked by practices.
As B. Spolsky argues, public linguistic space can be interpreted from the perspective of the language policy of "urban and developed environment - the city streets and squares, roads and parks, railway and bus station all places which are neither private nor institutional" (Spolsky, 2009: 65). PLS (public linguistic space) may include written material (public signs, newspapers and magazines, books), spoken content (announcements, radio, or television), or computers and

(c) Siberian Federal University. All rights reserved

* Corresponding author E-mail address: e-grishaeva@mail.ru; elena.grishaeva2@mail.ru 
Internet, reflecting a very biased picture of sociolinguistic reality.

Over the past decades, researchers from many areas are tempting to exhibit systematic description of linguistic profiles of present-day cities. It should be mentioned that the so-called "Linguistic landscape" has developed as a zone of cooperation among a wider spectrum of specialists. Sociolinguists, involved into studies of interdependence of all kinds of social and linguistic phenomena paid attention to the fact that public spaces are marked by linguistically formulated symbols, which relate to many social, economic, political and cultural grounds (BenRafael et al., 2006; Shoamy \& Gorter, 2008). The choice of language on a public sign appears to carry a high emotional value.

The term "linguistic landscape" was firstly used in a paper of R. Laundry and R. Bourhis (1997) reporting the perception of francophone school leavers of public signs in Canada. Then the French version of the "paysage linguistique" was applied by E. Ben-Rafael and his co-authors (2006) to the signs in Israeli communities.

A number of sociologist of language such as Y. Masai (1972) who had looked at the growing presence of English in Japan; J. Fishman et al. (1977) who had observed English and Hebrew signs in Jerusalem, they all had studied the topicality in question even earlier. They had found hips of English or "Romanized" script signs compared to what one could be expected to hear from the language spoken outside private places.

A collective monograph "Linguistic Landscape in the City" (2010) is a set of outstanding case studies of linguistic landscapes in the present-day urban settings, illustrating the widest range of variation that relates to cultural, social, political and economic circumstances. Under closer observation of the scholars are public space in Ireland, Japan, Israel, USA,
Latvia, Ukraine, Hong Kong, Korea, France and others.

Thus, since those pioneering investigations we could define a new approach to a study of the sociolinguistic ecology of modern cities being gradually adapted for tourists from different corners of the globe, and showing a greater tolerance for foreign languages.

\section{Theoretical Framework}

Global theme "Language and Society" in the modern social and economic context appears to gradually encounter new interpretations. Controversial language policy, language planning, political and sociolinguistic discourses on the local, national or supra-national levels of varied countries and institutionalized units come along with interdisciplinary and international integration under globalization.

Empirical experience of many multinational states evidences ineffective manipulation with language situations of different kinds. Therefore, language planning often tends to fail. Decisionmaking in linguistic domain can be successful if it matches spontaneous expectations of the majority of language users. In other words, group interests, connected with power and hierarchical subordination, distribution, resource and benefit allocation, prestige and influence, domination of one group over another in the employment sphere or in the sphere of access to education, culture, and information motivate decision-making processes.

Considering a language and social structures as dynamic phenomena, and recognizing a language being able to accommodate to changing political, economic and social conditions, introduced into ordinary usage a discussion on English and lesser-used modern foreign languages and its functions in every-day life of the residents of the Russian Federation.

Strictly speaking, society and rational features of practical actions in the domain 
of language planning were converted into a theory. Language users' preferences and concerns define a perception category and social connections not from the point of view of the reality, but from the perspective of their individual choice. In such circumstances, language policy stands for a propaganda of a particular language / languages, which are to serve socio-economic sphere.

\section{Statement of the Problem}

Treating public space as a domain for language management has added to the complexity of the sociolinguistic theory. Being a sub-field of language management, linguistic landscape is not always easily recognized and understood by the sign readers. Due to their preferences and choices, other participants such as sign producers, sponsors and potential audiences can aim at enforcing a particular language policy. Therefore, there might arise a concern on how to provide the feedback, monitor / check communicative effectiveness or even gain control of public space.

Being a sub-domain of language management, each public space has the owners of the sign, the producers of the written / spoken linguistic material, and an extra-domain authority (government) which has chosen to manage language choice in the domain. Living under globalization, when English is a Lingua Franca and a language of wider communication, language users face the ambivalent effect of globalization. Linguistic space is not under local control, i.e. the owner does not need to be in the particular country. Due to modern technological advances, there is room for a set of varied languages to be in everyday use in a form of printed or Web messages. If authorities conduct an official (central) language policy, there is room for controlling it. In the most of practical cases, public linguistic signs are open to the pressure of financial options and so of providing something that an audience is willing to pay for.

It is understood that further development of linguistic landscape will depend on consolidated contribution of different disciplinary areas. Their common understanding of linguistic landscape as symbolic frame of public spaces motivated us to look at the city of Krasnoyarsk (Russia) as a relevant social environment domiciled by people who live there and those who work there as advertising agents, designers of all kinds, investors and sponsors, local authorities, entrepreneurs and shop owners. We can therefore argue that linguistic landscape is a kind of a crossroad of professional and social interests.

It is worth mentioning in this respect, that B. Spolsky and R. Cooper proposed a conditions model explaining the choice of languages of the public space in the city (Spolsky, 1991). Summarizing their views, we can say that the first condition is "to write a sign in a language you know"... The second rule can be explained as the "presumed reader's condition": the sign is written in a language which can be read by the people you expect to read it (for instance, foreigners can read the signs in their language)". The third rule habitually represents the "symbolic value condition", i.e. a sign is written in the language with which you wish to be identified" (Spolsky, 2009: 69).

We can use this technique for studies of owners' approaches to brand their public places, shops of all kinds and kiosks in the city of Krasnoyarsk. As far as the study of linguistic landscapes focuses on analyzing public signage according to the language utilized, its relative saliency, syntactic or semantic aspects, the language facts which landmark the public space are predominantly social facts that, as such, relate to more general social phenomena" (Ben-Rafael, Shoamy \& Barni, 2010: xiv). 
Subsequently, the owners' and managers' choice in using different language signs evidence not their commitment to bilingualism or reflect their local literacy environment, but show the prestigious role of a particular language that might be assessed as a language on top / or associated as a dominating language in the consumerist sphere.

\section{Methods}

In the classroom within the Business English course, we informed twenty undergraduate students of the Institute of Economics, Management and Environmental Studies of the Siberian Federal University, located in the city of Krasnoyarsk, about the main aim, objectives and procedure of the study. The research questions identified aims to investigate the students' assessment of the city linguistic image, which conveys both semantic meanings and syntactic aspects. The selected students completed answering the questions and discussed the topicality of the investigation and their first impressions and assumptions on the way in which public linguistic space shares common principles in the development and implementation of organized language management.

They also studied material on brand names and their symbolic meanings, focusing on the insights into the use of language in the built environment.

Due to understanding the fact that material manifestations of language are an integral part of the urban public portrait and "constitute key elements in shaping city spaces as urban places imbued with social meanings" (Leeman and Modan, 2010: 182), we identified the research aim: to depict an evaluation of the elicited material and immaterial objects marked with linguistic tokens. Having got a set of the detailed instructions, the students started collecting data.

Along with evaluation research, the study developed a sampling of the linguistic landscape discursive power and its symbolic role. We also proposed a theoretical assumption for thinking about political, economic / commercial interests that manage the development of urban localities, bearing in mind the commodification of the city space.

Through semi-structured interviews, the qualitative data from the students / experts were researched and assessed later.

\section{Discussion}

As we have already defined, our narrow focus of research dealt with commercially centered public spaces overloaded with linguistic tokens. Thus, we were addressing our particular interest of research to the most popular downtown, business areas, and spots of entertainment in the city of Krasnoyarsk. It is situated in the middle of Russia, on the left and right banks of the river Yenisei. Being a centre of the main administrative bodies of the Krasnoyarsk region, a micro context of cultural, social and linguistic mixing, commercial and entertaining activities, Krasnoyarsk depicts a vivid interaction of business people, local authorities, and its population via vibrant and contemporary messages. According to the students' understanding, linguistic landscape reflects attire of the city of Krasnoyarsk as a part of activity of a global financial arena and countless innovative achievements.

Due to assumption that public signs can be read from the marketologists' outlook, we presume that they have two major functions - to communicate whether information, instruction, or persuasion, or to express a symbolic function to declare ownership or to express linguistic power (Cf.: Spolsky, 2009: 70). Having observed linguistic landscape of Krasnoyarsk, counted and photographed the linguistic tokens, the students concluded that a generic image of the city is presented metaphorically in a form of a reservoir full of human resources, their 
professionally induced competences and skills. Having also conducted a comparative research of the linguistic profiles of a range of big cities in the Russian Federation, they found that under contemporary globalized environment, a large amount of languages inhabit there. Both a state language (Russian), which is an official means of communication within the area in question, and the English language, which is a proud owner of its functional role nowadays worldwide, canvas a consumerist approach to the use of language combinations. The students of the Institute of Economics, Management and Environmental Studies think of themselves as consumers and a part of the city where they live and study. To their understanding, the linguistic landscape of Krasnoyarsk is significantly commercialized under globalized cosmopolitan trends. Consequently, they chose to restrict their analysis to commercial or shop front signs because they can help them to understand the individual strategies of shop owners.

Following the conditions model explaining the choice of languages proposed by B. Spolsky and R. Cooper in 1991, there should be several participants in the process of public signage: the owner of the sign, the sign maker and the presumed reader. There also might be a fourth party, a socalled language management authority which is responsible for the language policy either nationwide or locally. The latter implication does not seem to be considered neither by national nor local government. Possible interpretations of why the sign designer / maker has chosen a particular language look to be endless and not necessarily clear. In other words, we can evidence the absence of a constructive language policy or planning in this respect. The majority of consumers were unsure of what purpose it served. Some of them had not even noticed non-native language.

The choice of language for advertising is an important tool of language management.
Marketologists know how to choose correctly the language and style of their presumed consumers / readers. A thorough combination of linguistic signs and stereotypic associations relates to symbolic function. In other words, sign makers write in English for symbolic reasons: the signs written for people without proficiency produce stronger impact on them and their perception of the linguistic token. There is one more factor: the use of English seems to be perceived "as an index of sophistication, cosmopolitanism or modernity" (Leeman and Modan, 2010: 183).

From the marketing perspective, there are, as minimum, two major marketing strategies: standardization and customization. Globalization brought a big amount of internationally recognized adverts. Some of them were localized and accustomed to the national standards and tastes. It is understood, that locally reconsidered and modified global signs manifest a readiness to accommodate to the potential consumer.

We approach the linguistic landscape from the point of view of various languages present in the city and focus our analysis on qualitative issues: strategies of appropriation of space by written sign. Signs in English are mostly popular in the city of Krasnoyarsk. To provide some kind of illustrious examples, it is sufficient to have a look at the names of commercial spots in the central parts of Krasnoyarsk and other public spaces and find a greater frequency in English as well as other languages. Among the city signs, the Roman alphabet remains strong: it reveals both a complex and a significant pattern of language choice. For instance:

Restaurant-hotel complexes: Hilton Garden Inn Krasnoyarsk, Novotel Krasnoyarsk Center, Ibis Krasnoyarsk Center, Sky hotel, Soft_Hotel, AMAKS,B \& B Hostel, Miniotel24, Kras Apartment Service, Carlson, Weekend;

Food stores: Just Food, Al Pacino, SushiSan, Krasdragon, CupCake, Sweet home, Big sushi \& Roll, Lucky Luciano; 
Fast-food shops and restaurants: Burger King, Star Kebab, MyWOK, French Dogs, KrasPanda, KFC, Mama Roma, People's, Crystal, Chef Italiano, Chikki-pizza, Big Yorker, Quick Love Burger, Subway; Yoga-Bar, Hesburger, Franky Woo, Harley's, Broaster, BURGERS MEXICAN FOOD, Ibiza, T.G.I. Friday;

Bars: Buddha Lounge Bar, My favourite PUB $\times$ RESTAURANT $\times$ BAR MUNCHEN, NEW YORK (1+1 DRINK \& FUN) 24 OPEN, Music bar loft, Rock Juzz Café, Bookmaker pub (sport pub), Sally O’Briens, Riverbar BALKON, Harat's pub, Bak\$, lucky pub, KILLFISH DISCOUNT BAR, MAXito, L-city, Black Pearl;

Coffee shops and coffee houses: Traveler's Coffee, Coffeeline Espresso bar, GREENHOUSE - coffee shop, Mike\&Molly café-bar;

Hair studios and barber's shops, beauty/ spa/massage salons: Mods' hair Paris, Hair City, Elixir, BOOST-Up, Bad Boys Barbeshop, Chopchop, Concept Store \& Barbershop, Unique, GOLDWELL, Personal city, Infinity, Art \& Beauty, Wonderfil, Relax, Keit \& Leo, Matrix;

Fashion studios: Celebrity Lounge, Caramel, Rich, Beauty Time, Bliss, New Star;

Institutes of beauty: Babor, Maxim, Ultra, Radiance, Sun Street, Devine, In Style, Fantasy;

Fitness centers: Body Balance, Body Fly, FatAway, Sport \& beauty;

Premium class stores: Emporio Armani, Hugo Boss, Marina Rinaldi, Karen Millen, Lady \& Gentleman City, Sobranie, Trussardi;

Sportware: Nike, Adidas;

Mass market menswear, womenswear brands: Sysley,Guess, Bershka, Calzedonia, Intimissimi, Wisel, Gizia, Circle Boutique, Zara, Benethon, Mexx, Mango, Promod, Top Shop, Orsay, Wool Street.

As everyone can judge, all above-mentioned public spaces spotlight names in English and other lesser used languages (Italian/French).
The latter ones are not at a closer investigation in this paper. All these commercial quarters of the city exhibit consumption opportunities for passers-by, generally speaking, and for the younger generation, in particular. That is why there is one more condition to be bared in mind; the expectation of the sign initiator / maker that the potential clientèle and customers are interested in signs at all, and all names and signs would sound quite sweet for them, welcoming new comers, people of all ages and genders, who would be ready to consume new offers, pay for new impressions, taste new gastronomic combinations, indulge themselves to buy trendy clothes and shoe ware, entertain and have fun. These public places named in English have a symbolic meaning. That is why P. Backhaus has fit public signs into the study of language management.

Personal preferences, new fashion look, new local style, borrowings from foreign languages, more often from English, impact dramatically the linguistic landscape of the city of Krasnoyarsk. On the one hand, such a broken traditional linguistic environment could damage people's perception. On the other hand, the city and its young and active inhabitants keep going well in a new set of rules. They seem to accommodate easily chunky information, and get oriented in all those massive embodiments of concepts and emblems that had been earlier alien for their parents and grandparents. Very commonly in Russia, product names and brands are in a foreign language: they are generally targeted at younger audience. Within the frames of cultureconsumerist context, its players / students pay equal attention to comfortable environment, premium class consumer goods, and prestige, i.e. they are gradually becoming accustomed to the power of the particular culture code. The culture code is the unconscious meaning people apply to any given thing. 
Konrad Lorenz firstly applied a term, widely known as an "imprint", for depicting a combination of the experience and its accompanying emotion. "Once an imprint occurs, it strongly conditions our thought processes and shapes our future actions. Each imprint helps make us more of who we are". (Rapaille, 2007: 6). Therefore, the combination of the most memorable personal imprints defines us.

To sum up, we are referring to I. Pillar who had written once: "The audience can recognize that the message is in English and this activates values such as international orientation, future orientation, success, sophistication or fun" (Pillar, 2003: 174).

Studying the communicative function of advertisement, F. Grin (1994), a Swiss scholar and a provider of the economy of language, proposed a model to predict advertising choices in a bilingual and multilingual society. As B. Spolsky argues, "it showed the relation of sales to different language groups as the function of the level of advertising in each language, the language attitudes, the incomes, and an advertising response function. Indifference to language and the public can produce a monolingual commercial environment..." (Spolsky, 2009: 73). Moreover, there are multiple implications that foreign languages are frequently used in signage not for their communicative function, but for their symbolic value. For instance, H. KellyHolmes considers that "it is unimportant whether the advertisee understands the foreign words in an advertisement so long as it calls up the cultural stereotypes of the country with which the language is associated" (Kelly-Holmes, 2000: 67; Spolsky, 2009: 73).

This is how metacognitive mechanisms work when proceeding linguistic reality, which people were not familiar with before. Following O. Breidbach and J. Jost, E. Shoamy and E. BenRafael, we fully support their idea that "linguistic landscape represents by itself a gestalt, one whole, un ensemble (in French)" (Breidbach \& Jost, 2006; Ben-Rafael, Shoamy, Barni, 2010: xvi).

According to axiomatic remarks of the applied linguists and language scholars, one can anticipate that field researches can shed light to better understanding contextualized linguistic image of modern cities in different parts of the world. We believe that we can apply basic theoretical and methodological approaches to the analysis of particular linguistic manifestations and their intertwined correlations with principles of linguistic ecological environment of the Siberian cities, and understand the psychological and visual perceptions of the sign readers.

E. Haugen, an American sociologist of language, formulated the concept of "Linguistic Ecology" in 1959. Having used a wider steep analysis, he explained language changes via extra linguistic factors and formulated an idea of a socially modelled variation of language use, including language heterogeneity and variation, social relations, culture as a combination of behavioral norms. Thus, a core subject of sociolinguistics reached its identification.

Since then, power circles of varied multinational countries and states have stemmed from contrasting methodological and ideological basis and looked forward to prescribing or regulating language functions. In other words, authorities always tend to interfere the natural flow of languages, intending to balance specific features of different ethno groups, subjected to political and language management.

It will be also intriguing to reveal how much linguistic emblematic signs add decorative fleur to the Russian / Siberian cities and their multiliterate ecology. Firstly, urban Russian younger population shows readiness and loyalty to adopt this new linguistic code. Holistic picture of contemporary urban settings visualizes inner mechanism, which drives the city and its life 
from the point of view of the global village. It encompasses all possible types of consumer goods, human experience and professional activities. Linguistic and constructivist structure of the social context aims at providing comforting ambience for the city population and developing its day-to-day culture.

The mixture of languages is an evident result of growing globalization. Even if foreign languages are not understood, the sign makers exploit symbolic associations written in uncomprehended languages. In terms of linguistic context, signs in English are reinforced contextually through their location at the area as themed landscapes (shopping malls, entertaining parks and spot grounds). Due to a wider scope of values, mindsets and cognitive differences, people interpret linguistic landscape images differently; therefore, their axiological reactions to linguistic landscape displays also tend to be versatile. Previously identified hypothesis was the more diversified were linguistic signs, the wider would be the youngster's emotional replies to them.

It was worth investigating how visual perception of public spaces' linguistic decorations correlated to emotional perception of brand names of the high street shops, as well as restaurants, recreational areas entitled in English. A thorough data evaluation after interactive interview between an interviewer and respondents served a basis of qualitative research that reflected dynamic process of understanding the meanings of the names. All the participants of the given communicative framework have undergone a shift to service-based economies of early $21^{\text {st }}$ century. Consequently, commercial interests influence material manifestations of language in urban historical or cultural environments. We can note everywhere a sort of intertwining of cultural symbols and entrepreneurial capital. J. Leeman and G. Modan argue that "in the symbolic economy, cultural symbols play a significant role in selling of products and services, and entrepreneurs invest in projects that rely on cultural symbols to attract consumers. Further, culture, products and services are bundled together and marketed as "experiences" (Ibid.: 185). J. Hannigan assumed that cities are slowly converting into consumer-friendly urban spaces. "Retailers promote the concept of "shopertainment", in which shopping is conceived of as a leisure activity, rather than a chore ... cities are fun" (Hannigan, 1998). Economists consider that not only culture provide added value to commodities, but those commodities also impute economic value to culture" (Crawford, 1992). Material manifestations of language can enhance particular commodities and serve "as vehicles to spatialize the commodification of culture; encountering a foreign language can give visitors the sense of having visited an authentic place" (Leeman and Modan, 2010: 192).

\section{Conclusion}

Sociologists of language turned to get interested in discursive means of linguistic landscape. Linguistic illustrations stem from varieties of resources reflecting a myriad of cultural, social, political and economic circumstances. In the light of the findings, we can say that the delivered research reflects accommodation of the young generations' visual perception to their emotional responses to linguistic landscape of the city.

We have taken into consideration one more factor. Krasnoyarsk is mostly a monolingual city. At first glance, the city is officially monolingual, impervious to the process of language contacts at all. On the contrary, due to the marketing revolution, linguistic landscape of Krasnoyarsk is far from being trivial: popular zones of commercial activity play with the symbols of multicultural economic environment. Ironically, English is on 
the front stage of the linguistic portraying and decorating residential and commercial facades. This fact goes against the linguistic management strategies of the Russian population. Its intrinsic immunity to foreign languages in general, and to English, in particular, does not save the city of Krasnoyarsk of the worldwide geopolitical trends.

While forsighting language functions, their potential development and societal needs in urban setting, sociologists of language should take into consideration multi-disciplinary approaches. This task appears to be the toughest one. Presumably, exploration of the domain calls then for an enriched theory of language management, but sets complex challenges for a workable methodology (Spolsky, 2009: 89). Throughout the exposition of our theoretical framework, we provided a set of examples, primarily from the city of Krasnoyarsk (Russia), to show how non-native languages come onto a stage as strategic tools in modern urban redevelopment initiative and the construction of "destination locations" for residents and visitors of the city. We also can think of so called "intentional aesthetization of language $\langle\ldots$, as when letter size, font style and sign colors are dictated in planning and zoning documents that standardize the visual qualities of the built environment" (Leeman and Modan, 2010: 193). It means that for the city of Krasnoyarsk and its residents the signage in English can cast its value and purpose as solely aesthetic, not being used for communicating any semantic content.
What we attempted to do in this study was to envisage a particular example of multilingualism in the city of Krasnoyarsk via instances of written language displayed on commercial shop fronts.

\section{Acknowledgements}

The paper is based upon research I have conducted with the students of the Institute of Economics, Management and Environmental Studies of the Siberian Federal University (Krasnoyarsk, Russia). The idea of the research was made possible after my participating in August 2014 at the 17-th World Congress of the International Association of Applied Linguistics in Brisbane, Australia. I have been acquainted with Professor Elana Shohamy, a bright scholar from Tel Aviv University. Her plenary presentation "Linguistic Landscape Research as a Means for Broadening Language Policy Theory and Practice" inspired me to study linguistic landscape from multi-layered perspectives of the city of Krasnoyarsk where I live and work.

My grateful acknowledgment is made to Professor Elana Shohamy who developed the concept of "linguistic landscape" into the study of languages and their representations in public space in contexts of multilingualism, visual literacy, language management and policy. This approach enables sociolinguists at correcting people's everyday linguistic life and experiences via negotiating desired linguistic realities and their meanings.

\section{References}

Ben-Rafael, E., Shohamy, E., Amara, M.H., \& Trumper-Hecht, N. (2006). Linguistic landscape as symbolic construction of the public space: The case of Israel, In International Journal of Multilingualism, 3 (1), 7-30.

Ben-Rafael, E., Shohamy, E. \& Barni, M. (2010). Introduction: An Approach to an "Ordered Disorder". In Linguistic Landscape in the city. Bristol, Buffalo, Toronto, Multilingual Matters (xi-xxviii).

Breidbach, O., Jost, J. (2006). On the gestalt concept, In Theory in Biosciences, 125 (1), 19-36. 
Crawford, M. (1992). The World in a Shopping Mall, In M. Sorkin (ed.) Variations on a Theme Park (3-30). New York, Hill and Wang.

Fishman, J., Cooper, R., and Conrad, A.W. (1977). The Spread of English: The Sociology of English as an Additional Language. Rowley, MA: Newbury House.

Grin, F. The Bilingual Advertising Decision, In Journal of Multilingual and Multicultural Development 15 (2-3), 269-292.

Grishaeva, E. (2015). Linguistic Landscape of the City of Krasnoyarsk, In Procedia - Social and Behavioral Sciences 200, 210-214.

Hannigan, J. (1998). Fantasy City. London, Routledge.

Haugen, E. Planning for Standard Language in Modern Norway, In Anthropological Linguistics, 8.

Kelly-Holmes, H. (2000). Bier, Parfum, Kaas: Language Fetish in European Advertising, In European Journal of Cultural Studies, 3 (1), 67-82.

Landry, R. \& Bourhis, R. Y. (1997). Linguistic landscape and ethnolinguistic vitality: An empirical study, In Journal of Language and Social Psychology, 16 (1), 23-49.

Leeman, J., Modan, G. (2010). Selling the City: Language, Ethnicity and Commodified Space, In Linguistic Landscape in the City (182-198).

Masai, Y. (1972). Living Map of Tokyo, Jiji Tsushinsha.

Pillar, I. (2003). Advertising as a site of language contact, In Annual Review of Applied Linguistics 23, 170-183.

Rapaille, C. (2006). The Culture Code. New York, Broadway Books, 213 p.

Shohamy, E. \& Gorter, D. (2008). Linguistic Landscape: Expanding the Scenery. New York, Routledge.

Shohamy, E., Ben-Rafael, E. and Barni, M. (eds.). Linguistic Landscape in the City. Bristol, Buffalo, Toronto, Multilingual Matters, 354 p.

Spolsky, B. (1991). Hebrew Language Revitalization within a General Theory of Second Language Learning. In R.L. Cooper \& B. Spolsky (eds.), The Influence of Language on Culture and thought: essays in Honor of Joshua A. Fishman's Sixty-Fifth Birthday (137-155), Berlin: Mouton de Gruyter.

Spolsky, B. (2009). Language Management. Cambridge, CUP, 308 p. 


\section{Коммерчески ориентированное \\ общественное (публичное) \\ языковое пространство \\ русского города, оформленное \\ посредством англоязычных вывесок}

\section{Е.Б. Гришаева}

Сибирский федеральныгй университет Россия, 660041, Красноярск, пр. Свободный, 79

В данной статье нашли свое отражение общченаучные положения о всеобщей связи, взаимной обусловленности и целостности явлений и процессов окружающего мира. Исследование проведено в русле изучения социолингвистического дискурса, предметом которого явилось выявление особенностей оформления лингвистического облика современного города, вызывающего у пользователей языка определенную психоэмочиональную реакиию. Обозначенная тематика вскрывает общественный характер развития и функиионирования языков, а такэе обосновьвает активные действия и социальную мотивацию широкого корпуса специалистов смежных наук - лингвистов-прикладников, социолингвистов, специалистов по межкультурной коммуникации. Работа отвечает общей тенденции в современной науке к интегрированию знаний, использованию междисичиплинарных подходов к анализу языкового материала.

Ключевые слова: социолингвистический дискурс, языковое оформление общественных мест, лингвистический ландиафт, обозначение торговых мест.

Научная специальность: 10.00.00 - филологические науки; 24.00.00-культурология. 